\title{
Magarsos Antik Kenti Oluşum Kurgusunun Analizinde Sistematik Bir Yaklaşım
}

\author{
Yelda Durgun Şahin ${ }^{1 *}$, M. Faruk Altunkasa ${ }^{2}$ \\ 1 Çukurova Üniversitesi, Mimarlık Fakültesi, Peyzaj Mimarlığı Bölümü, Adana, Türkiye (ORCID: 0000-0001-6708-9247) \\ ${ }^{2}$ Çukurova Üniversitesi, Mimarlık Fakültesi, Peyzaj Mimarlı̆̆ı Bölümü, İstanbul, Adana (ORCID: 0000-0003-4449)
}

(İlk Geliş Tarihi 14 Ocak 2020 ve Kabul Tarihi 29 Şubat 2020)

(DOI: 10.31590/ejosat.688942)

ATIF/REFERENCE: Şahin Durgun, Y. \& Altunkasa, M. F. (2020). Magarsos Antik Kenti Oluşum Kurgusunun Analizinde Sistematik Bir Yaklaşım. Avrupa Bilim ve Teknoloji Dergisi, (18), 348-358.

$\ddot{\mathbf{O} z}$

İnsanlar, kentleşme sürecine avcılık ve toplayıcılık yaparak önce mağara, çadır ya da oba gibi geçici yerleşimlerde, daha sonraki süreçte tarım ve hayvancılık yaparak kalıcı yerleşmelerde yaşamışlardır. Gelişen yerleşik hayat düzeniyle birlikte ticaret olgusu başlamış ve insanlar önce yakın daha sonra uzak çevreleri ile etkileşim kurmuşlardır. Bu etkileşim ile kentler gelişmiş, kültür alış-verişi sağlanmış ve toplulukların inanç sitemleri arasında farkındalıklar ortaya çıkmıştır. Bu olgulardaki değişimler kent gelişimine katkı sağlamakla birlikte kent planlama kararları ve mekân kurguları üzerinde etkilerini belirlemiştir. Tarihte kentler sosyal, kültürel ve fiziksel bir oluşum ve etkileşim sonucunda gerçekleşmiştir. Bir kentin oluşumundaki arka planın okunabilmesi için, o kenti sosyal, kültürel ve fiziksel oluşum süreçleri doğrultusunda, multidispliner bir çalışma ile değerlendirmek gerekmektedir. Bu değerlendirmenin nasıl bir yöntem ile analiz edilebileceği ise çalışmanın temel çıkış noktasını oluşturmuştur. Bu çalışmanın amacı, tarihi anlamanın somut bir aracı olan, antik kentler için, çok boyutlu antik kent analiz modeli ölçütlerinin oluşturulmasıdır. Bu doğrultuda öncelikle araştırma alanının sinırları belirlenerek, tarihten günümüze Anadolu topraklarının bir parçası olan Ovalık Kilikya bölgesi antik kentlerinden Magarsos kenti seçilmiştir. Geliştirilen analiz modeli ölçütleri Magarsos antik kenti üzerinde uygulanarak, sosyo-kültürel, coğrafi ve tarihsel belirleyicilerin alt grupları tanımlanmış ve Magarsos antik kent envanteri oluşturulmuştur. Sonuç olarak bu çalışma ile antik kentlerin okunabilirliğine katkı sağlayan sistematik veriler, Magarsos antik kentinin oluşumundaki arka planın okunabilmesine katkı sağlamıştır. Ayrıca bu çalışmada kullanılan yöntem ile, kentsel arkeoloji alanında, farklı antik kent çalışmaları üzerinde yapılacak diğer kapsamlı çalışmalara katkı sağlayacağı düşünülmektedir.

\section{A Systematic Approach to the Analysis of the Formation Structure of Magarsos Ancient City}

\begin{abstract}
People lived in temporary settlements such as caves, tents or oba, and then settled in permanent settlements by farming and animal husbandry. With the developing settled life order, the phenomenon of commerce started and people first interacted with their close and then distant circles. With this interaction, cities have developed, cultural exchange has been provided and awareness has emerged among the belief systems of the communities. Although the changes in these phenomena contribute to urban development, they have determined their effects on city planning decisions and space constructions. In history, cities have been realized as a result of social, cultural and physical formation and interaction. In order to be able to read the background in the formation of a city, it is necessary to evaluate the city with a multidisciplinary study in line with the social, cultural and physical formation processes. The method by which this evaluation can be analyzed is the main starting point of the study. The purpose of this study is to create multi-dimensional ancient city analysis model criteria for ancient cities, which is a concrete tool of understanding history. Accordingly, firstly, the borders of the research area were determined and Magarsos city was chosen as one of the ancient cities of Ovalik Cilicia region, which is a part of Anatolian lands from the past to the present day. By applying the developed analysis model criteria on the ancient city of Magarsos, subgroups of socio-
\end{abstract}

\footnotetext{
* Sorumlu Yazar: Çukurova Üniversitesi, Mimarlık Fakültesi, Peyzaj Mimarlığı Bölümü, Adana, Türkiye, ORCID: 0000-0001-6708-9247, ydurgunsahin@,cu.edu.tr
} 
cultural, geographical and historical determinants were identified and Magarsos ancient city inventory was created. Consequently, systematic data contributing to the legibility of ancient cities with this study contributed to the legibility of the background in the formation of the ancient city of Magarsos. In addition, with the method used in this study, it is thought that it will contribute to other comprehensive studies on different ancient city studies in the field of urban archeology.

Keywords: Magarsos, Analysis Criteria of Ancient City, Ancient City Inventory

\section{Giriş}

Uzun tarihsel oluşum ve gelişim sürecinden geçmiş olan, toplumun yaşam biçimi, kültürel değerleri ve inanç sistemleri bütününden oluşan ve toplumsal dinamikler ile oluşturulan, geleneksel konut mimarisi gibi kentlerde farklılaşan yaşam biçimi, kültürel değerler ve inanç sistemleri çerçevesinde bölgenin yerel coğrafik özellikleri doğrultusunda şekillenmişlerdir (Güngör ve Özcan, 2019). Şekillenen bu kentler, onları farklı kılan nitelikleri ve biçimleri doğrultusunda tanımlanmışlardır. Bu tanımlamalar, kimi zaman, "Bronz Çăg 1 kenti, Ortaçağ kenti, Roma kenti” gibi dönemsel bir atıf, kimi zaman "Osmanlı kenti, Yunan kenti, Türk kenti ya da Arap kenti” gibi ait olduğu medeniyet ya da ulusa atıf, kimi zaman "İslam kenti” gibi egemen dini inanca dair bir atıf ya da, “Akdeniz kenti” gibi içinde yer aldığ 1 coğrafyaya yönelik bir sınıflandırma doğrultusunda coğrafi bir atıfla değerlendirilmiştir (Ünlü, 2017, s. 75). Lynch, kentleri farklılaştıran bu özelliklerin, kentin kimliğini oluşturduğunu belirtmiştir (Ünlü, 2017,76; Lynch,1981). Kentlerin aynılıklarını ve farklılıklarını ortaya koymak için dönemsel, medeniyetsel, dinsel, bölgesel, tarihsel, sosyal, iklimsel olmak üzere pek çok girdilerle değerlendirmemiz gerekmektedir.Bu bağlamda kentler, disiplinlerarası ilişkilerin bir ürünü olarak karşımıza çıkmaktadır. Bir disiplin kente ait verileri, kendi disiplin alanı sınırları içerisinde değerlendirmektedir. Bir kentin tüm yönleriyle değerlendirilerek tanımlanması için farklı disiplin alanlarının ortaya çıkarmış oldukları bulguların, bir arada kullanılması gerekmektedir. Bu bağlamda multidispliner bir çalışma yöntemi ile, bir kentin oluşumundaki tüm bileşenler, o kenti okumamıza yardımcı olabilmektedir.

Lynch (1960) kent formunun değerlendirilmesindeki bu multidisipliner çalışmayı, fonksiyon, yoğunluk, makroform ve bu faktörlerin birbiri ile ilişkileri olarak üç temel unsur altında incelenmesi gerektiğini belirtmiştir(Şekil 1) (Lynch, 1960).

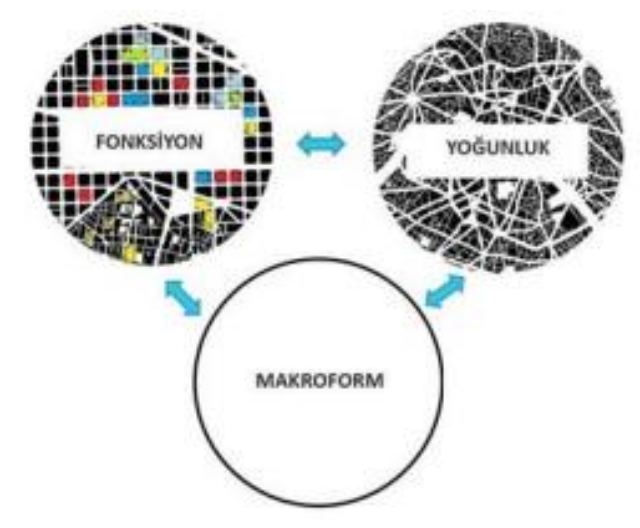

Şekil 1: Kent Formunun Temel Unsurları (Lynch, 1960)

Bu doğrultuda bu çalışma Magarsos antik kentinin makroformu üzerine yoğunlaşmış, Magarsos antik kentinin kent kurgusunu anlamak ve tanımlamak için, kent üzerine çeşitli bilim dalları tarafından kullanılabilen belirleyicilerin kent üzerinde etkilerinin değerlendirilmesine odaklanmıştır. Ölçütler oluşturulurken, mimarlık, şehir ve bölge planlama, arkeoloji, antropoloji, ulaşım, tarih, jeoloji, kent ve insan coğrafyası gibi pekçok bilim dalına ait belirleyicilerden yararlanılması gerekliliği ortaya çıkmıştır. Bu doğrultuda, antik kentlerin kent kurgularının anlaşılabilirliğinin ve tanımlanabilirliğinin sağlanması için, kent kurgularının biçimlenme ölçütlerinin belirlenip, bu ölçütlerin gruplandırılması ile kent belirleyicileri oluşturulmuştur. Sonuç olarak belirlenen kent belirleyicilerinden oluşan analiz model ölçütleri, örneklem alanı olan Magarsos antik kenti üzerinde uygulanmış ve kentin bir akdeniz liman kenti, koloni kent, dinsel merkez özellikleri taşıdı̆̆ 1 , kentte çeşitli yaşam biçimi örgütlenmesinden doğan yapılaşmaların bulunduğu, kentin kuzey güney yönelimli olarak kurulduğu, komşuluğunda bulunan Mallos kenti ile olan ilişkisinin kent için büyük anlama sahip olduğu sonucuna varılmıştır.

\section{Materyal ve Metot}

Çalışma; Magarsos antik kentinin, kent analiz modeli ölçütleri kullanılarak kent bulgularının elde edilmesi, kent envanterinin oluşturulmasını içeren farklı yöntemlerin kullanıldığı geniş kapsamlı bir metodolojiyi içermektedir. Çalışmanın kurgusu iki temel aşamadan oluşmaktadir.

- Antik kent analiz modeli ölçütlerinin belirlenmesi,

- Antik kent envanterlerinin oluşturulmasıdır.

Bu ölçütler oluşturulurken aşağıdaki methodolojik çalışmalardan yararlanılmıştır.Bunlar;

$>$ Antik kent plan şemaları (Garfiksel teknik ile çizim)

$>$ Antik kent dokularına ait hava fotoğrafları (Google Earth Pro)

$>$ Literatür verileri (Çeşitli tarihi belge ve akademik çalışmalar, dijital kütüphane)

$>$ Gözlem verileri 
Mevcut kent plan ve haritalar (1/1000 ölçekli antik kent planları ve ölçeksiz antik kent krokileri)

$>$ Antik kente ait haritaların geliştirilmesi (Autocad 2018, Photoshop) olarak belirlenmiştir.

Antik kentlerin organizasyon kurgularını anlamak için kentin ortaya çıkış amacını anlamak ve tanımlayabilmek gerekmektedir. Kente dair fiziksel bileşenlerin birbirleri ile olan etkileşimi yanında, sosyo-kültürel, ekonomik ve jeolojik bileşenlerin ilişkisini anlamak gerekmektedir. Bu tanımlamaları yapabilmek için de kente doğru sorular yöneltmek gerekmektedir. Bu çıkış noktasıyla toplumların ne tür mekânlarda yaşadıklarını anlamak ve toplumun yansıması olan kentlerin kentleşme süreci içerisindeki oluşum kurgularını analiz etmek için de Tablo 1' de belirtilen ölçütler belirlenmiştir.

Tablo 1. Mekân Analizi için Temel Ölçütler (Şahin, 2019'dan geliştirilmiştir, s. 43)

\begin{tabular}{|l|l|}
\hline Toplumların Ne Tür Mekânlarda Yaşadığını Anlamak Iç̧in Temel Alınan Ölçütler \\
\hline Kentin Formu & Ortak Kullanım Alanları \\
\hline Kentte Kullanılan Ana Malzemeler & Özel Kullanım Alanları \\
\hline Yapıların Yönlenmesi & Tarih Öncesi Dönemleri \\
\hline Kentin Konumu & Kentin uğradığı doğal afetler \\
\hline Kent Yapılarının Çatı Formu & Kentin uğradı̆̆ doğal afetler \\
\hline Yapıların Bitişik ya da Ayrık Düzende Uygulanması & Kentlinin Örgütlenme Biçimleri \\
\hline Kentin Alt Öğeleri & Kentte Kullanılan Semboller \\
\hline Kentin Kapladığı Alan & Kentin Kısıtları \\
\hline Komşu Kentler & Kentin Olanakları \\
\hline Kentin İnşa Edildiği Topoğrafya ve İklim Verileri & Kentin Geçim Kaynakları \\
\hline Kentin Ulaşım Ağı ve Kentin Kalkınmaya Etkileri & Kentin Oluşum Kurgusu \\
\hline
\end{tabular}

Kente bu belirlenen ölçütler doğrultusunda sorular sorarak aldığımız cevaplar ile kentin tanımlanabileceği düşünülmüştür. Her bir ölçüt değerlendirildiğinde bunların da üst formda ve belirli disiplin dalları çerçevesinde gruplanabileceği görülmüştür. Gruplamada kentle ilgilenen çeşitli bilim dallarının disiplin sınırları içerisinde ve kent olgusunun şekillenmesine öncü olan,

- Coğrafi Belirleyiciler,

- Sosyo-Kültürel Belirleyiciler,

- Tarihsel Belirleyiciler olarak üç temel ölçüt belirlenmiştir.

Bu üç temel ölçüt, antik kentlerin yerleşim özelliklerinin, nasıl olduğunun ve ne üzerine kurulduğunun özetlenmesi, hangi sosyokültürel yapının üzerine inşa edildiklerinin anlaşılabilmesi, yerleşim bölgesinin coğrafik belrileyicilerinin kente sağlamış olduğu katkıların tanımlanabilmesi açısından gerekli görülmüştür. Ayrıca Kilikya bölgesinin kronolojik olarak kimler tarafından yönetildiğinin incelenmesi, kentlerin önemli tarihsel kırılma noktalarının belirlenmesi ve kentlerin kısa ve uzun dönemdeki değişim süreçlerinin anlaşılmasına katkı sağlayacağı düşünülmektedir. Bu bağlamda ana belirleyici gruplama çerçevesinde, alt belirleyiciler sınıflandırılarak Tablo 2' de yer alan Antik kent analiz modeli ölçütleri tanımlanmıştır. Böylece oluşturulan model ölçütleri doğrultusunda, herhangi bir antik kentin, kent kurgusu sistematik olarak tanımlanabilecek ve antik kent envanteri oluşturularak kent okumasına destek olunabilecektir. 
Tablo 2. Antik Kent Analiz Modeli Ölçütleri (Şahin, 2019, s. 44)

\begin{tabular}{|c|c|c|}
\hline \multirow{3}{*}{ 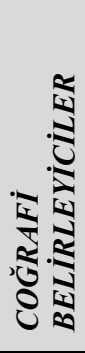 } & İklim & $\begin{array}{ll}\text { - } & \text { Kent Girişlerinin Konumu } \\
\text { - } & \text { Yapıların Yönlenmesi } \\
\text { - } & \text { Kent Yapılarının Çatı Formu } \\
\text { Yapıların Bitiş̧ik ya da Ayrık Düzende Uygulanması }\end{array}$ \\
\hline & $\begin{array}{l}\text { Topoğrafya/ } \\
\text { Konum }\end{array}$ & $\begin{array}{l}\text { - Topoğrafik Yükseltiye Göre Kentin Konumlanması } \\
\text { - Kent Teraslamaları } \\
\text { - Kent Biçimlenmesi (Simetrik/Asimetrik) } \\
\text { - Komşu Kentler }\end{array}$ \\
\hline & Malzeme & - Kentte Kullanılan Yap1 Malzemeleri \\
\hline \multirow{3}{*}{ 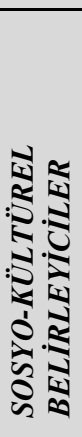 } & Yaşam Biçimi & $\begin{array}{ll}\text { - } & \text { Kentin Ana Geçim Kaynağı } \\
\text { - } & \text { Kent Kullanım Biçimi } \\
\text { - } & \text { Kentte Yapılan Eylemler } \\
\text { - } & \text { Kentlinin Örgütlenmesi Bireylerin Edindiği Roller } \\
\end{array}$ \\
\hline & $\begin{array}{l}\text { Kentin Yapısı// } \\
\text { Büyüklüğü/ } \\
\text { Ulaşım A Ağı }\end{array}$ & $\begin{array}{ll} & \text { Kent Alanı Sinırları } \\
\text { - } & \text { Kent Formu } \\
\text { - Kent Kullanım Şeması } & \text { Kentin Diğer Kentlerle Olan Bağlantısı } \\
\end{array}$ \\
\hline & $\begin{array}{l}\text { Kent Öğglerinin } \\
\text { İlişkileri }\end{array}$ & $\begin{array}{ll}\text { - Ortak Kullanım Alanları } \\
\text { - Özel Kullanım Alanları } \\
\end{array}$ \\
\hline \multirow{2}{*}{ 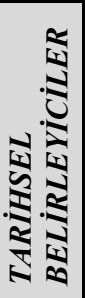 } & $\begin{array}{l}\text { Tarih Öncesi ve } \\
\text { Tarih Dönemler } \\
\text { İçinde Kent } \\
\end{array}$ & $\begin{array}{ll} & \text { M.Ö } 3500 \text { Öncesinde Oluşan Yerleşimler } \\
\text { - } & \text { M.Ö } 3500 \text { Sonrası( İlk Çağ-Orta Çağ-Yakın Çağ-Yeni } \\
& \text { Çağ'da ortaya çıkan yerleşimler) } \\
\end{array}$ \\
\hline & $\begin{array}{l}\text { Kentin Tarihi } \\
\text { Kırılma Noktaları }\end{array}$ & $\begin{array}{ll} & \text { Kentin Uğradı̆̆ı İşgal } \\
\text { - } & \text { Kentin uğradığı doğal afetler (Deprem, Sel vb.) }\end{array}$ \\
\hline
\end{tabular}

\section{Araştırma Sonuçları ve Tartışma}

Ovalık Kilikya toprakları, geçmişi neolitik döneme kadar uzanması ve birçok uygarlığa ev sahipliği yapması gerçekliğiyle zengin kültürel birikime sahiptir. Bölge Neolitik dönem, Hitit dönemi, Pers dönemi, Seleuka krallı̆̆ dönemi, Roma dönemi, Bizans dönemi, Selçuklu dönemi, Osmanlı dönemi ve günümüz Türkiye'sine kadar ulaşan zengin tarihi geçmişe sahiptir. Şekil 2' de Kilikya bölgesine ait antik kentler ve Magarsos antik kentinin bölge içerisindeki konumu yer almaktadır.

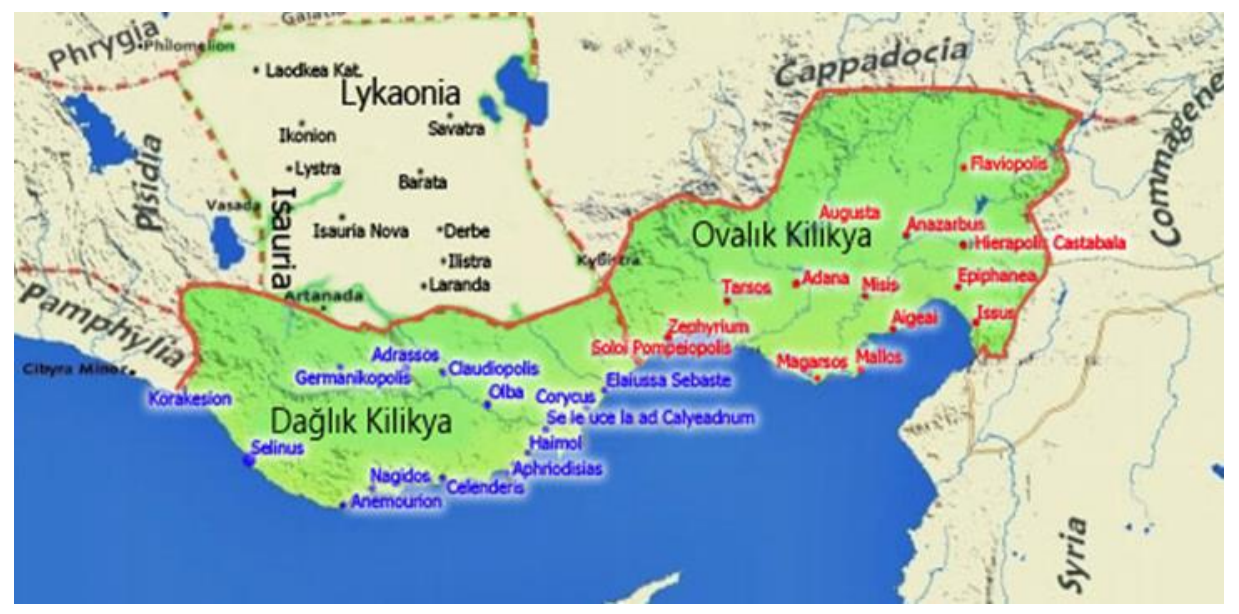

Şekil 2. Dağllk ve Ovalık Kilikya Bölgesi İçerisinde Yer Alan Antik Kentler (Bilir, 2014’ten geliştirilerek)

\subsection{Magarsos Antik Kenti Tarihi Belirleyicileri}

Arrian, Plinius, Stephanus ve Strabon gibi yazarların kaynaklarında Magarsa, Magarsos, Megarsus (Mó́ $\alpha \rho \sigma \alpha$, Mó́ $\alpha \rho \sigma o \varsigma$,

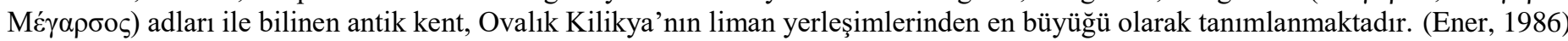

Magarsos'un kuruluşunu mitolojik bir olayla açıklayacak oluırsak; Strabon, Troia Savaşı sonrası bölgeye gelerek Mallos kentini kuran Apollon'un oğullarının aralarında yaşanan iktidar mücadelesi sonucunda yapılan düelloda Magarsos'ta hayatlarını kaybettiklerini ve mezarlarının da bu kentte bulunduğunu ifade eder (Strabon, 1993). Arrian kentin bir grup Argoslu tarafindan kurulduğunu 
aktarmaktadır (Ener, 1986). Bossert ise Pompeius’un eski korsanları yerleştirdiği kentler arasında yer almış olduğunu belirtir. (Bossert, 1950). Homerous'un İlyada'sında, Truva savaşçısı Misisli Mapsos, Truva'da savaştıktan sonra Kilikya ya dönerken, Yunanlı arkadaşı Akhad halkından Anflakos'u beraberinde getirir. İki savaşçı bugün ki Karataş'ın 5 km batısında Magarsus Antik Kenti'ni beraber kurarlar. M.Ö.1184 yilında Magarsus un tek hakimi olma mücadelesi veren Mapsos ve Anflakos, denizi seyreden Magarsus Amfi Tiyatro da ölümüne bir dövüş yaparlar ve dövüş Anflakos'un ölümüyle sonuçlanırken, ağır yaralanan Mapsos da fazla yaşamaz (Anonim, 2013). Amerikalı arkeolog Marjory Veronica Seton Williams ve ekibi tarafından kent incelenmiş ve bir Roma yerleşimi olduğu belirtilmiştir (Williams, 1954). Sayar (1999), Karataş Burnu'nda bulunmuş olan bir onurlandırma yazıtındaki açıklamalara göre ticari ve askeri liman kenti olarak IV. Antiochos tarafından M.Ö 3. yüzyılın son çeyreğinde Antiocheia adıyla kurulmuş olduğunu ve Mallos kentinin yerine inşa edildiğini belirtmektedir (Sayar,1999).

Magarsos'un kuruluşunu çeşitli tarih kaynaklardan açıklayacak olursak;

- Geç Hellenistik dönemde (M.Ö. 3-M.Ö. 2) Pyramos (Ceyhan) Nehri batısında Kızıltahta Köyü yakınlarında kurulduğu ve nehir taşkınlarının taşıdığı alüvyonların altında kalarak önemini yitirdiği düşünülmektedir (Sayar ve Öztürk 2010).Karataş Burnu'nda bulunmuş olan bir onurlandırma yazıtındaki açıklamalara göre ticari ve askeri liman kenti olarak IV. Antiochos tarafından M. Ö 3. yüzyılın son çeyreğinde Antiocheia adıyla kurulmuş olduğunu ve Mallos kentinin yerine inşa edildiğini belirtmektedir (Sayar,1999). Karataş Burnu'nda ele geçen 102 parça keramik buluntularının kronolojik dağılımının kentin M.Ö 3. ve 2. yüzyıla tarihlendiği belirtilmiştir (Şahin, 2014).

- Yunanlar' ın hakimiyetinde olan kent bir dönem Pers yönetiminde kalmıştır (Ünal 2006)

- Büyük İskender 330 yılında İssos’ta Pers kralını yenerek bölgeye hâkim olmuştur (Erhan, 2016).

- M.S. 2'nci yüzyılda yaşamış olan antik coğrafyacı Arianos'un aktardığına göre; Büyük İskender'in Ceyhan Nehri'nin üzerine bir köprü inşa ettirip Magarsus kentine geldiği, antik tiyatronun 200 metre kuzeyindeki Athena Magarsia Tapınağı'nı ziyaret ettiği, sunularda bulunduğu, daha sonra kentin efsanevi kent kurucusu Anflakos' un mezarını ziyaret ettiği, sonra da buraya çok yakın olan Mallos'a geçtiği aktarılır.

- Sonra Selekos Krallı̆̆ hakimiyetinde kalmış.

- Daha sonra da Roma denetimine girmiştir. Roma denetimi bölgede M.S. 260 yılına kadar devam etmiş, ardından Doğu Roma İmparatorluğu bölgede hakimiyete başlamış.

- 4 ve 7. yüzyıllar arasında Bizans hakimiyeti,

- 8 ve 10. yüzyılda İslami seferlerle Abbasi dönemi yaşanmış.

- Kent kapılarından birinin üzerinde Ermeni Kraliyet armasının yer almış olmasından dolayı kentin bir dönem Ermeni hakimiyetinde olduğu anlaşılmıştır (Ener, 1986).

- $\quad$ 10. yüzyıldan itibaren tekrar Bizans hakimiyeti başlamış

- $\quad 12,13,14$. yüzy1llarda Memluk hakimiyeti ortaya konulmuş.

- Daha sonra 15. yüzyılda Osmanlı'ya bağlı Ramazanoğlu Beyliği hakimiyetini görüyoruz. Daha sonra da doğrudan Osmanlı'ya bağlanıyor ve günümüze kadar tarihsel süreci geliyor (Erhan, 2016).

Günümüzde de izleri görülebilen kent surlarının doğu batı yönünde yol sistemi ile eşzamanlı yapılmış olduğunu ve 1zgara planlı kent şemasına sahip Helenistik bir kentin savunma sistemine ait olduğunu belirtmiştir (Sayar, 1999). 2006-2009yılları arasında, jeofizik teknikler kullanılarak yapılmış olan yüzey araştırmasında ise sur duvarlarıyla çevrili kentin, 1zgara planlı bir Hellenistik Dönem kenti olduğu belirtilmiştir (Rosenbauer, 2007).

\subsection{Magarsos Antik Kenti Coğrafi Belirleyicileri}

Kentin kuzeyinde Adana, güneyinde Akdeniz, doğusunda Akyatan gölü, batısında ise Aigeai antik kenti yer almaktadır. Bir ova üzerinde konumlanan ve denize bakan yamaçları yüksek bir falez görünümünde olan yerleşimin kıyı şeridinde doğal kumsallar ve kumul setleri ile deniz arasında sı̆̆ ve suları tuzlu, çevresi bataklık lagünler yer almaktadır. Akdeniz ikliminin egemen olduğu yerleşimin jeomorfolojik yapısı çoğunlukla alüvyon alanlardan oluşmaktadır (Dikmen ve Toruk, 2017).

Adana ili Karataş ilçesi sınırları içerisinde bulunan antik kent üç tarafı denizle çevrili olması nedeniyle tarihte önemli liman kentlerinden biri olmuştur. Mallos kentinin nehir taşkınları sonrası alüvyonlar altında kalması sonucu, bu kent halkının taşındığ yerleşim yeri olarak bilinmektedir. (Sayar, 1993). Mallos'un, taşkınlar nedeniyle önemini yitirerek alüvyonal toprağın altında kaldığı, böylece M.Ö. 3. yüzyılın son çeyreğinden itibaren terk edilerek yerini Magarsos’a bıraktığı anlaşılmaktadır (Sayar, 2011).

Antik Magarsos kenti, liman aracılığıyla ticaret yapılmasını kolaylaştırması ve Ceyhan nehri kıyısında kurulmuş olan Mallos, Mopsouhestia (Misis), kentlerinin deniz bağlantısını sağlamış olması açısından, stratejik öneme sahip olmuştur (Altay, 1965). Doğal limana sahip olan bu antik kentte artan ticaret ilişkileri nedeniyle ilerleyen dönemlerde dalgakıranların eklenmiş olduğu ve limanın genişletildiği bilinmektedir. Magarsos kentinin önce liman kent olarak kurulduğu ileri dönemlerde ise artan mal ve ticaret talebi ile genişlediği düşünülmektedir.

Sahanın delta ovası olması ve Akdeniz iklimine sahip olması nedeniyle, zengin toprak özelliğine sahip olmuş ve tarımsal verimliliği artırmıştır. Yılda en az iki kez ürünün alındığı bölgede tarım, geçmişten günümüze önemli bir geçim kaynağı olmuştur (Kafalı Yılmaz, 2019). Göney çalışmasında eski kıyı çizgisinin Mersin'den doğuya Kazanlı’ya, buradan Ağzıdelik, Çöplü ve Kuransa köyleri yakınından geçmiş olduğunu, bu hattan da Dervişler mevkisine ve güneydoğuya doğru Domuz Tepe'ye yöneldiği tespit edilmiştir (Göney, 1976). Bu bilgiler ışığında dönemin kıyı çizgisini belirleyecek olursak aşağıdaki Şekil 3'de ulaşılabilmektedir. Bu doğrultuda M.Ö II. binde Misis, Tarsos ve Adana antik kentlerinin Akdeniz kıyısına çok yakın oldukları görülmektedir. M.Ö II. binde Ovalık Kilikya bölgesinde var olmayan antik kentlerinin ise Magarsos, Mallos antik kentleri olduğu öngörülmüştür. Bu doğrultuda Ceyhan e-ISSN: 2148-2683 
nehrinin taşımış olduğu alüvyonlu toprağın denizde dökülmesiyle zamanla bu delta ovası oluşmuş ve yerleşim alanı olarak kullanılmış olduğunu düşündürmüştür.

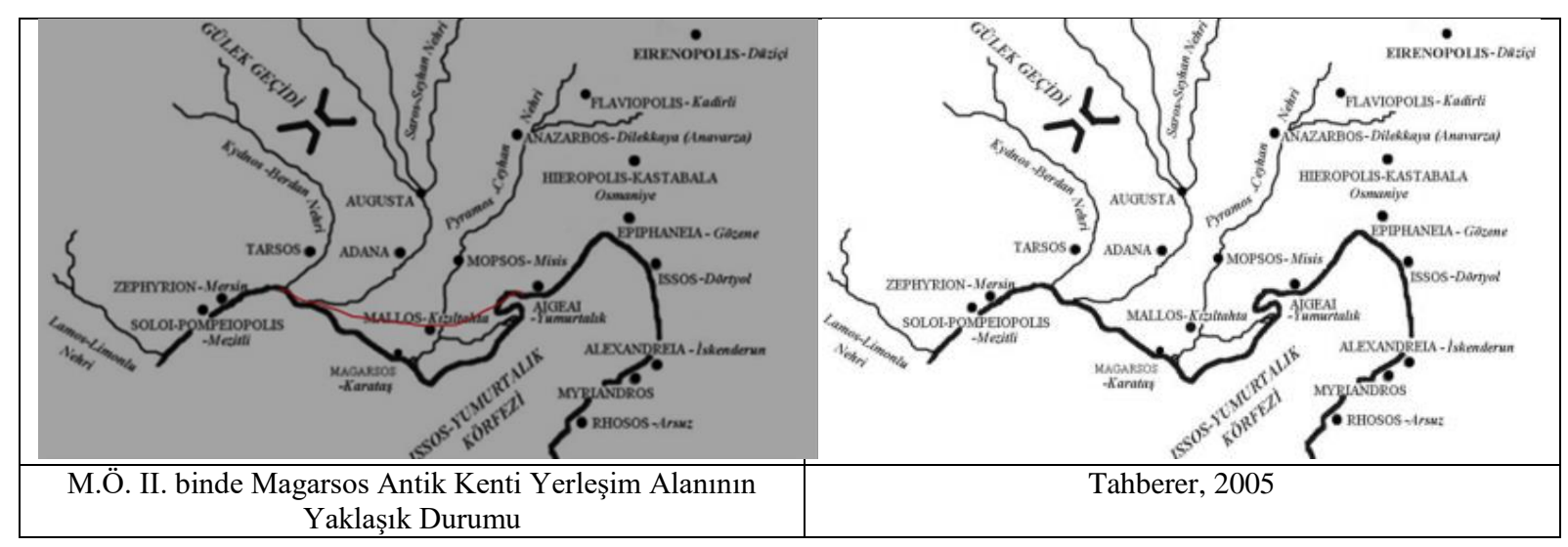

Şekil 3. M.Ö II. binde varolduğu düşünülen kiyl çizgisi ile Ovalık Kilikya haritasında araştırmada incelenen antik kenterin konumları (Tahberer, 2005 ve Google earth hava fotoğrafi)

Prof. Bossert çalışmalarında Magarsus kentinin kalesinin sağ batısından Ceyhan nehrinin denize döküldüğünü ve ticari yük gemileri, Magarsus denetiminde kalenin dibindeki batı kenarından Ceyhan nehrine girerek, bugünkü Kızıltaha köyünde yer alan antik Mallos kentine ulaşarak, getirdikleri yağ, şarap, sabun ve zeytini satıp, buradan da tahıl, baharat, ipek ve canlı hayvan taşınmış olduğunu belirtmektedir. Aynı zamanda gemilerin Misis'e ulaştıklarından da bahsetmektedir (Bossert, 1950).

Tahberar haritasında Ceyhan nehrinin batı komşuluğunda belirtmiş olduğu Mallos antik kenti, günümüzde toprak altında kalmış olması ve antik çağ gezginlerinin tariflenmiş oldukları coğrafyanın değişmiş olmasından dolayı yer tespiti ile ilgili çeşitli görüşler bulunmaktadır.

Durukan (2017), çalışmasında, Ptolemaios'un Mallos'u Pyramos'un doğusuna yerleştirmiş olduğunu, Romalı tarihçi Q. Curtius Rufus'un ise, İskender'in Magarsos'tan Mallos'a bir köprü aracılığıyla ulaşmış olduğundan bahsettiğini, bununda Magarsos Ceyhan nehrinin batısında olduğu için Mallos'un doğu yer aldığı șeklinde yorumlanması gerektiğinde bahsetmektedir. Heberdey-Wilhelm de Mallos'u Pyramos Nehrinin doğusunda aramak gerektiğini vurgulamışlardır (Heberdey ve Wilhelm, 1896). Bossert ise Mallos'u Pyramos'un batı kıyısına yerleştirmektedir (Bossert, 1950). Magie, bu görüşü desteklemekte ve kenti Pyramos'un sağ kıyısında (batı) aramak gereğine dikkat çekmektedirler (Magie,1950). Mallos'un, taşkınlar nedeniyle önemini yitirerek alüvyonal toprağın altında kaldığı, böylece M.Ö. 3. yüzyılın son çeyreğinden itibaren terk edilerek yerini Magarsos'a bıraktığı anlaşılmaktadır (Sayar, 2011). Magarsos kentinin de M.S. 333 yılında Suriye ve Kilikya' da yaşanmış olan veba salgın ile sonrasında çıkan isyanın neticesinde kentin gerilemeye geçtiği bilinmektedir. Bu neticeyle birçok coğrafik belirleyicilerin öncülüğünde Magarsos antik kentini oluşturduğu, şekillendirdiği ve yok ettiği görülmüsstür.

\subsection{Magarsos Antik Kenti Sosyo-Kültürel Belirleyicileri}

Antik kentlerdeki mimari ve estetik yapı ile toplumsal yaşam ve düşünsel yaşam arasında doğrudan bir ilişki bulunmaktadır. Dönemin düşünce ve yaşam tarzının dönüşmesiyle oluşan kentler varlıklarıyla bize dönemin yaşam biçimi hakkında çeşitli bilgiler sunmaktadır.

Hellen yaşamında, bütün kent belirli bir tanrıya ait olmuştur (Wycherley, 2011). Magarsos antik kenti de M.Ö. 140 yılına tarihlenen bir yazıtta Magarsos kentinde bulunan tanrıça Athena Magarsia'ya adanmış tapınağın varlığı tespit edilmiştir (Sayar, 1999). Bu bilgi ile kentin tanrısının Magarsia olduğu söylenebilir. Tanrılarla kent arasındaki ilişki, bazı kültlerle bina arasındaki ilişkiye benzer nitelikte olmuştur. Bu bağlamda önemli yapılarda bulunan sunak ve heykeller mitolojik inanışlar çerçevesinde bahsi geçen kişiye adanmış ürünler olarak karşımıza çıkmaktadır.

Eski Yunanların ürettiği ilk edebi eser olan Homerous'un İlyada'sı, Geç Tunç Çağı'nda yapılmış Troya Savaşı'ndan esinlenilerek üretilmiş olduğu bilinmektedir. Savaşın taraflarından birisi Akhalar, diğeri Troyalılardır. 10 yıl boyunca devam eden bu savaşın Troya merkezli olarak devam etmediği farklı cephelerde de savaşılmış olduğu belirtilmiştir. İnanç sistemleri gereği savaşın tarafı olan Athena tanrısı Akhaların tarafını tutmaktadır (Kaya, 2017). Magarsos antik kentinde yer alan tapınağın Athena Magarsia olarak adlandırılması, şavaşın farklı bir cephesi olan doğu akdeniz limanında Akhaların kazanarak tanrıya şükürlerini göstermenin bir türü olarak yorumlanabileceği düşünülmüştür.

Antik Çağlar boyunca kentler; siyasi, ekonomik ve sosyal yaşamın merkezleri olduğu için, her kent bu işlevlerini yerine getirecek, kentsel yapılara ihtiyaç duymuştur. Bu kentsel yapıların nereye, ne şekilde yapılacağı konusu; M.Ö. 6. yüzyıldan itibaren kent plancılığını gündeme getirmiştir. (Fidan, 2016). 
Liman kentleri, denizaşırı toplumların uğrak ve geçiş yeri olduklarından en başta kullanılan dil açısından üretim ve tüketim ilişkileri bakımından, sosyal yaşam ve davranış kalıpları açısından, dünyalık işlerin yürütümü noktasında evrensel hukuk ve ulusal hukuk örgütlenmeleri açısından, çoğulculuğun koordinasyonu zorunluluğunu görmekteyiz

Helenistik dönemde başlayan kolonizasyon, hammadde arayışı için kentten uzaklaşan topluluklar ile başlamıştır. Ana kentten uzaklaşan kolonilerin yeni yerleşimleri hızlı bir şekilde oluşturma istekleri, düzenli kent plancılığının ilerlemesini hzılandırmıştır. Yeni pazarlar, hammaddeler ve yeni topraklar bulma çabası ile Yunanlılar M.Ö 8. yüzyılda başlayarak Akdeniz çevresinde yerleşimler kurmuşlardır (Mansel, 1995).

İskender'in Asya seferleri sonrasında, Yunan kültürünün doğuya yayılması sonucu ortaya çıkan kozmopolit ve seküler Helenistik dönem başlar. Bu dönemde Yunan kültürü kendi içine kapalı olmaktan çıkmış ve savaşlar sonucunda kurulan yeni imparatorluğun halkları ile etkileşime geçerek kültürel farklılaşma yaşamıştır (Bilal, 2019).

Magarsos' da antik Yunan kültür dünyası dört aşamada şekillenmiştir

1. Aristoteles ile gelişen klasik Yunan felsefesi dar anlamda yine Aristoteles ile beraber sona ermiştir. (Hellen Dönemi)

2. İskender'in Asya seferleri sonrasında başlayan Yunan kültürünün doğuya yayılması sonucu ortaya çıkan yeni oluşum ile kültürel birliktelikler oluşmuştur.

3. Yeni oluşuma bir tepki olarak ortaya çıkan Yunan pagan dininin doğu dinlerinin etkisiyle, dini problemler, felsefi bir dil içinde yorumlanmaya başlanmıştır.

4. Son olarak da Yunan düşüncesinin doğu dinlerine teslim olduğu, Hıristiyanlık, Zerdüştlük gibi dinlerin etkisi altında, Yunan düşüncesinin dinsel bir dünya görüşüne dönüştüğü ve dinsel problemlere odaklandığı bir dönem gelişmiştir (Bilal, 2019).

Magarsos Antik Kentinin, Ovalık Kilikya'nın önemli sahil kenti Mallos'un kutsal bir mekânı ve bir uydu kent (genel olarak Mallos kentine bağımlı, Mallos'un yakınlarında oluşmuş bir yerleşim) olduğu düşünülmektedir (Verner, 1951).

Bazı onurlandırma yazıtlarında ticari ve askeri liman olarak Mallos kentinin yerine kurulduğu ifade edilmektedir (Sayar, 1999). M.Ö. 140 yılına tarihlenen bir yazıtta Magarsos kentinde bulunan tanrıça Athena Magarsia'ya adanmıs tapınağın dönemin önemli kehanet merkezlerinden biri olduğu ifade edilmektedir (Sayar, 1999). Bu bağlamda kentte ticari, askeri ve dini örgütlenmenin olduğundan söz edilebilir.

M.Ö.2.yüzyılın ortalarında Rodos'un etkinliğininkaybolması, Akdeniz'de tehdit oluşturan korsanlara karşı Roma İmparatorluğu tarafından gerçekleştirilen müdahaleler, Kilikya'nın siyasal ve kültürel yapısını değiştirmiş olmalıdır (Ünal ve Girginer 2007) Korsanlar, Romalılar ve taht kavgaları nedeniyle giderek zayıflayan Seleukos yönetiminin Kilikya'yı koruyamadığı, yerleşimin Ermeni Kralı Tigranes tarafından işgal edildiği (M.Ö. 83), yeni kurulan başkent Tigranokerta'ya (Silvan) zorla götürülen bölge halkının ancak Roma egemenliği döneminde yurtlarına dönme olanağı bulduğu (M.Ö. 68) aktarılmaktadır (Sayar, 2000).

Multidispliner bilgiler içeren bu çalışmada, kent olgusunun şekillenmesine öncü olan, coğrafi, sosyo-kültürel, tarihsel belirleyicilere ait bulgular değerlendirilerek Magarsos antik kenti için Tablo 3'de yer alan sistematik bulgular oluşturulmuştur. Böylece bugüne kadar yazılı olan multidispliner çalışmaları özetleyerek birlikte görüp değerlendirme olanağı sunulmuştur. 


\begin{tabular}{|c|c|c|}
\hline \multicolumn{3}{|c|}{ MAGARSOS-KARATAŞ ANTIK KENT ANALIZ MODELİ BULGULARI } \\
\hline \multirow{3}{*}{ 量 } & İklim & $\begin{array}{ll} & \text { Kent Girişlerinin Konumu: Kuzey giriş } \\
\text { - } & \text { Yapıların Yönlenmesi: Kuzey -Güney yönünde } \\
\text { - Yapıların Bitişik ya da Ayrık Düzende Uygulanması: Ayrık } \\
\text { düzende }\end{array}$ \\
\hline & Topoğrafya & $\begin{array}{ll} & \text { Akdeniz kıyı liman kenti } \\
\text { - } & \text { Üc tarafi denizle çevrili } \\
\text { - } & \text { Mallos kentinin uydu kenti (Durukan, 2017) } \\
\text { - } & \text { Musis ile Ceyhan nehri üzerinden bağlantıll } \\
& \text { Kuzey-Güney yönelimli }\end{array}$ \\
\hline & Malzeme & - Yerel Kireçtaş1, Tuğla, Mermer \\
\hline \multirow{3}{*}{ 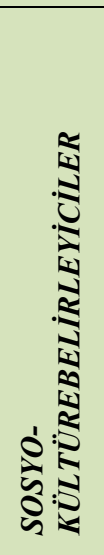 } & Yaşam Biçimi & $\begin{array}{ll}\text { - } & \text { Kentin Geçin Kaynağı: Ticaret-Balık üretimi } \\
\text { - } & \text { Kent Kullanım Biçimi: Askeri Deniz Donanma Üssü-Koloni } \\
& \text { Kent-Dini Merkez-Uydu Kent } \\
\text { - } & \text { Kentte Yapılan Eylemler Kentlinin Örgütlenmesi: Askeri } \\
& \text { Örgütlenme-Dini Örgütlenme -Ticari Örgütlenme } \\
\text { - } & \text { Kentte Bireylerin Edindiği Roller- Tüccar-Aile bireyi-Asker }\end{array}$ \\
\hline & $\begin{array}{l}\text { Kentin Yapısı/ } \\
\text { Büyüklüğü }\end{array}$ & $\begin{array}{ll} & \text { Liman Kent-Helenistik dönem askeri koloni kent } \\
\text { - } & \text { Kent Formu: Geç Helenistik dönem-Roma Dönemi- Arap } \\
& \text { Dönemi- Ermeni Krallık döneminde şekillenmişstir } \\
\text { - } & \text { Kent Kullanım Şeması: Kuzey Güney ana aksında } \\
\text { - } & \text { Kentin Büyüklüg̈ü: Roma dönemi yaklaşı } 2 \text { km }^{2} \\
\end{array}$ \\
\hline & $\begin{array}{l}\text { Kent } \\
\text { Öğelerinin } \\
\text { Varlığı }\end{array}$ & $\begin{array}{l}\text { Ortak Kullanım Alanları: Tiyatro, Kilise, Hamam, Tapınak, } \\
\text { Stadion, Gymnasion, Nekropol, Sarnıç, Ana cadde, Liman } \\
\text { - Özel Kullanım Alanları: Konut }\end{array}$ \\
\hline \multirow{2}{*}{ 䒺 } & $\begin{array}{l}\text { Tarih Öncesi } \\
\text { ve Tarih } \\
\text { Dönemler } \\
\text { İçinde Kent }\end{array}$ & $\begin{array}{ll}\text { - } & \text { Geç Helenistik Dönem } \\
\text { - } & \text { Roma Dönemi } \\
\text { - } & \text { Bizans Dönemi } \\
\text { - } & \text { Orta Crağ Dönemi } \\
\text { - } & \text { Ermeni Dönemi } \\
\end{array}$ \\
\hline & $\begin{array}{l}\text { Kentin Tarihi } \\
\text { Kurılma } \\
\text { Noktaları }\end{array}$ & $\begin{array}{l}\text { - } \quad \text { Pyramos'un s1k sık yatak değiştirmesi } \\
\text { - Kentin kuzey kesiminin alüvyonla dolması ile topoğrafyanın } \\
\text { değişmesi }\end{array}$ \\
\hline
\end{tabular}

Bu bilgiler doğrultusunda ve taranan kazı raporları sonucunda Tablo 4' de Magarsos Antik Kenti envanteri oluşturularak kenti bütüncül olarak tanımamız sağlanmıştır. Bu envanter çalışması, antik kentin kullanım amacını, jeopolitik önemini, mekânsal öğelerini ve kent planını ayrıntılı olarak ortaya koymaktadır. Antik kentlerin okunabilirliğine katkı sağlayan ve sistematik veriler içeren Magarsos antik kent envanter çalışması, kentin oluşumundaki arka planın okunabilmesine katkı sağlamıştır.

Tablo 4. Magarsos-Yumurtalık Antik Kenti Envanteri

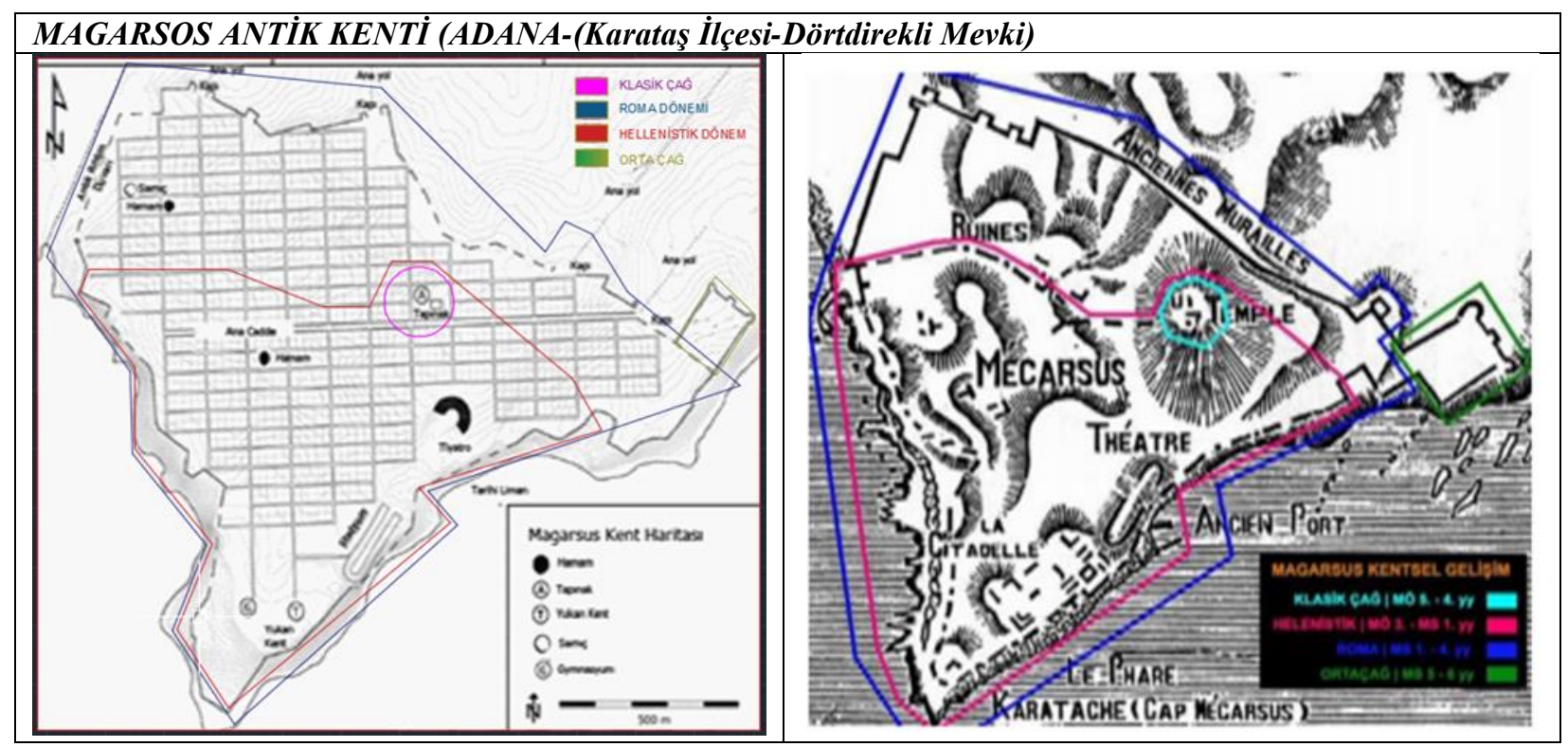




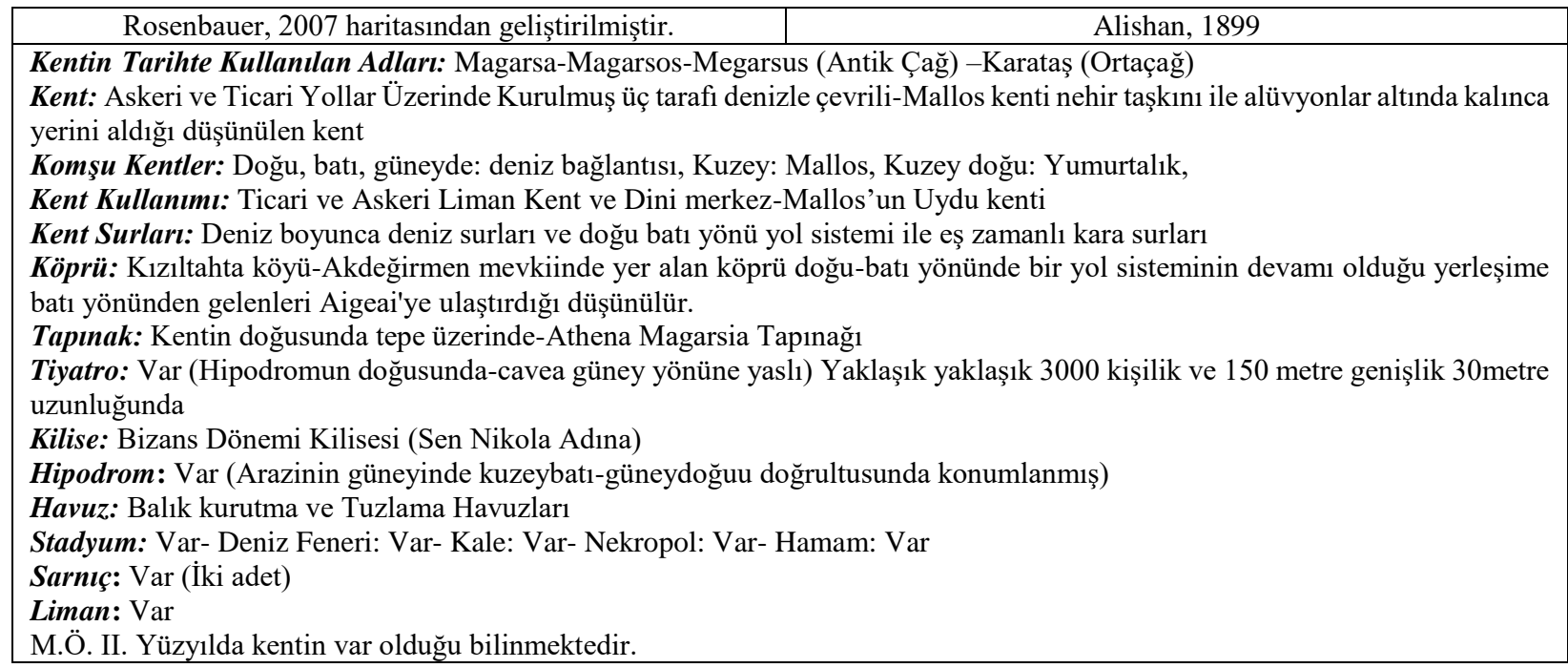

\section{Sonuç}

Antik kentlerin kazı süreçleri uzun yıllar almaktadır. Kazı alanında yıldan yıla yeni ulaşılan bilgiyle, o güne kadar edinilmiş bilgiler harmanlanmakta ve yeniden değerlendirilmektedir. Bu değerlendirme sürecine başlamadan multidisipline bir yaklaşımla kente dair yapılmış olan çalışmaları bütünsel olarak görmek ise kentin kurgusu hakkındaki değerlendirme sürecine katkı sağlayacağını düşündürmüştür. Böylece kent analiz modeli doğrultusunda, tarihsel, sosyo-kültürel ve coğrafi belirleyicileri sayesinde Magarsos antik kentinin okunabilirliğine dair, Magarsos antik kenti analiz modeli ölçütleri ile Magarsos antik kent envanteri oluşturulmuştur. Bu çalışmada ayrıca kentin mimari, arkeolojik bulgularına dair önemli sonuçlara ulaşılmıştır.

$\checkmark \quad$ Klasik dönemde yerleşim ağında sokakların aynı ölçüde olduğu ve baskın hatlar bulunmadığı görülmüştür. Ayrıştırılan yapı adalarının büyüklükleri dönemine göre çeşitlilik göstermiştir. 5.yüzyıl'ın sonlarına doğru ise, ana trafiğin yoğunlaştığı hattın diğerlerinden daha geniş olması ihtiyacından kenar parsellerden alınarak parsellerin küçültülüp, caddelerin genişletilmiş olduğu düşünülmektedir (Tanaç, 2000). Bu bilgiler ışığında kent tarihlemesi yaparken antik bir kentte insula sistemi ile ana aks-sokak genişlik ilkesine bakarak da kente dair okuma yapılabilmektedir. Magarsos antik kentinde sadece doğu batı yönündeki genişlemenin ana yol aksı komşuluğunda bulunan insulala boyutlarını küçültmediğinden dolayı, bu yol aksının Roma değil Hellenistik dönemde kentin kurulması aşamasında planlanmış olduğunu göstermiştir.

$\checkmark$ Gelişmiş olan koloni kentler önceden tasarlanmış bir plan dahilinde kurulmuştur. Kentin doğrultusu, güneş, su ve rüzgar yönü hesaplanarak tespit edilmiş ve trafiği düzenlemek için geniş ve düzgün caddeler dik açıyla kesişmiştir. Kuyular açılmış, gerektiğinde yer altından borularla su getirilmiş, kirli suların toplanması için kanalizasyon sistemi geliştirilmiş ve bunu uygulamak içinde binalar gruplandırılmıştır. Geç Hellenistik Dönemde kurulmuş olan kentlerde insula içlerinde binaların işlevlerine göre gruplandırıldığg görülür. Magarsos antik kentinde hamam yapısının ana cadde komşuluğunda yapılmış olması ana aks cadde boyunca bir kanalizasyon ve su sitemi ile yapıya su sağlanmış olacağını düşündürmektedir. Erken Hellenistik dönemde ise yapılarda anıtsallık kavramı gelişmiştir. Kent için daha çok kentin imgeleri anlam taşımaktadır. Kente ait erken Hellenistik dönem örneği olan Magarsia tapınağı da bu anıtsallık ile kentin imgesini oluşturmuştur.

$\checkmark$ Kentte yer alan $1 / 2$ oranında düzenli insula ebatlarının bulunması kentin Helenistik dönemde demokrasi ile yönetilen dönemde inşa edildiğini vurgulanmaktadır.

$\checkmark$ Magarsos' un jeopolitik konumu, doğunun (Asya) veya batının (Antik Yunan, Makedonya, Roma ve Bizans) ticari ilişkisine öncülük etmek dışında, farklı sosyo-kültürel değerlerinde iletişimine sebep olmuşlardır.

$\checkmark \quad$ Magarsos kenti halkı, savaşın yıkıcı etkisinden korunmak, kendileri ve kentlerini korumak, ticaret yaptıkları ürünleri korumak, limanlarını korumak için kent duvarları örmüş oldukları görülmektedir.

$\checkmark$ Antik dönemde yaşayan halkın yaşadıkları kentte tanrıyı kişiselleştirmiş oldukları bilinmektedir. Tanrının kenti koruduğu, kentin de tanrıya ait olduğu düşüncesiyle tanrıya adanan tapınakların kurulduğu görülmektedir. Magarsus' da yer alan Athena Magarsia tapınağı tek tanrılı dine geçmeden önce, inanmış oldukları tanrılardan birine adanmış yapı olarak karşımıza çıkmaktadır.

$\checkmark \quad$ Magarsos antik kentlerinde doğu-batı yönünde decumanus aksının bulunduğu, cardo aksının yer almadığı saptanmıştır.

$\checkmark$ Hellenistik dönem kenti olan Magarsos' un liman ve nehir bağlantısını ile kent dişı bağlantılarında ticareti kullanıyor olmasının bir sonucu olarak Yunan düşünce yapısı ile doğu etkisinde kalmış bölge topraklarının düşünce yapısının kültür alış-verişi kurarak sentezlenmesinde öncülük etmiş olduğu öngörülmüştür.

$\checkmark$ Magarsos antik kentinin Hellenleşmesinde yani Hellen kenti özelliği taşımasında koloni kenti olarak kurulmasının büyük katkısı bulunmaktadır.

$\checkmark \quad$ Çalışmadan elde edilen bulguların, Magarsos antik kenti kazı alanlarının yönetimine multidisipliner bir yaklaşımla veriler sunması açısından katkı sağlayabileceği düşünülmektedir. 
Bu veriler ışığında tarihi anlamanın somut bir aracı olan antik kentler için, çok boyutlu kent analiz modeli ölçütleri oluşturulmuştur. Arkeolojik kentlerin okunabilirliğine katkı sağlayan ve sistematik veriler ortaya koyması açısından önem taşıyan bu çalışmada, kullanılan yöntemin benzer özyapıdaki diğer kentlerde de benzer ya da değişkenlik gösteren biçim ve içerikle kullanılabilirliğine ve antik kentler arası karşılaştırmanın yapılabilmesine olanak sağlamaktadır. Bu çalışmada belirtilen sistematik belirleyiciler sayesinde, kent okumalarını destekleyici bütüncül bir yaklaşımın sağlanacağı öngörülmektedir

Kentsel arkeoloji alanındaki çalışmaların sınılı sayıda olması nedeniyle çalışma yönteminin bu alandaki farklı kapsamlı çalışmalara katk1 sağlayacağı düşünülmektedir. Bu çalışmada yapılan inceleme, araştırma ve gözlemler sonucu elde edilen bulgular ve öneriler çerçevesinde, diğer antik kentlerin analiz edilmesi ve kent kurgularına dair sistematik okumanın sağlanabilmesi ile kentler arasındaki benzerlik ve farklılıkları kıyaslamanın, tarihsel sürecin analitik çerçevede değerlendirilmesine olumlu katkılar sağlayabileceği öngörülmüştür.

\section{Kaynakça}

Alishan, L. M., (1899). Sissouan ou L’Arméno-Cilicie. Des Description Sous Les Auspices.

Géographique et Historique. Venise-S. Lazare: Publié

Altay, M, H., (1965). Adım Adım Çukurova, Adana.

Anonim., (2013). https://www.haberler.com/bakan-celik-magarsus-antik-kenti-kazilarini-5111413-haberi/ (erişim tarihi: 15.01.2020).

Bilal, A., (2019). https://www.filozofunyolu.com/helenistik-donem/helenistik-donem-ve-epikuros/ (erişim tarihi: 01.02.2020).

Bilir, A., (2014). Roma Dönemi Doğu Akdeniz Deniz Ticaretinde Kıyı Kilikya Bölgesinin Yeri ve Önemi doktora tezi. Selçuk Üniversitesi Sosyal Bilimler Enstitüsü Arkeoloji Anabilim Dalı Klasik Arkeoloji Bilim Dalı, Konya.

Bossert, H, Th., (1950). "Karataş'taki arkeolojik araştırmalar hakkında kısa ön rapor. $\quad$ Belleten XIV, 661-666.

Dikmen, Ç ve Toruk, F., (2017). Magarsos Antik Kenti Anıtsal Yapılarının Korunmasına Yönelik Öneriler. Social Science Studies Cilt 5, Say1 9, s. 41-64.

Durukan, M., (2017). Yeni Veriler Işığında Mallos, Magarsos ve Antiokheia Pyramos Problemi, OLBA XXV.

Ener, K., (1986). Tarih Boyunca Adana Ovasına Bir Bakış, 103-110, İstanbul.

Erhan, F., (2016). Tarihte Adana ve Çukurova Cilt I. İlkçağ’dan Ortaçağ’a Adana ve Çukurova (Edt: Yılmaz Kurt, Fatih Sansar), s. 279-306, Adana.

Fidan, A., (2016). Kent Akademisi | Kent Kültürü ve Yönetimi Hakemli Elektronik Dergi | Cilt: 9 Sayı: 3 Sonbahar 2016 sayfa 86.

Göney, S., (1976). Adana Ovaları, İstanbul.

Heberdey, R., Wilhelm, A., (1896). Reisen in Kilikien, Wien.

Kafalı, Yılmaz, F., (2019). Adana Ovaları'nda Endüstriyel Tarım Bitkilerinin Üretimindeki Değişiklikler. Atatürk Üniversitesi Sosyal Bilimler Enstitüsü Dergisi, 23 (3), 973-986.

Kaya, M, A., (2017). Troya ve Troya Savaş1: Efsane ve Tarih, Akademik-der Tarih, Eğitim, Bilim ve Kültür Dergisi 1, 1-14.

Lynch, K., (1960). The Image of the City. Cambridge, Massachusetts, London: The MIT Press.

Lynch, K., (1981). A Theory of good city form. Cambridge, Massachusetts, London: The MIT Press.

Magie, D., (1950). Roman Rule In Asia Minor, Princeton.

Mansel, A. M., (1995). Ege ve Yunan Tarihi, T.T.K, Ankara.

Özcan, U ve Güngör, S., 2019. Geleneksel Türk Evi ile Geleneksel Japon Evi'nin Yapısal Açıdan Karşılaştırılması, Avrupa Bilim ve Teknoloji Dergisi, Sayı 16, S. 646-661.

Rosenbauer, R., (2007). “Topographisch-Urbanisitischer Survey des Ruinengeländes am Kap Karataş/Türkei”, Vorbericht zur ersten Kampagne 2006. HASB 20, 107-119.

Rosenbauer, R., (2007). “Topographisch-Urbanisitischer Survey des Ruinengeländes am Kap Karataş/Türkei”, Vorbericht zur ersten Kampagne 2006. HASB 20, 107-119.

Sayar, H, M., (2000). "Kilikya'da Epigrafi ve Tarihi Coğrafya Araştırmaları 2000”, XIX. Araştırma Sonuçları Toplantısı- II, Milli Kütüphane Basımevi, Ankara.

Sayar, M, H., (1999). “Kilikya'da Epigrafi ve Tarihi Coğrafya Araştırmaları1999”, XVIII. Araştırma Sonuçları Toplantısı, I, Milli Kütüphane Basımevi, s. 275-288.Ankara.

Sayar, M, H., (1999). Kilikya'da Epigrafi ve Tarihi Coğrafya Araştırmaları1999”, XVIII. Araştırma Sonuçları Toplantısı- I, Milli Kütüphane Basımevi, s. 275-288, Ankara.

Sayar, M, H., (2011). “Çukurova Yüzey Araştırmaları 2011”, XXX. Araştırma Sonuçları Toplantısı II, Çorum, 2013. 
Sayar, M. H., (1993). Doğu Kilikya'da Epigrafi ve Tarihi-Coğrafya Araştırmaları 1991. Araştırma Sonuçları Toplantısı, X, Ankara.

Sayar, M. H., Öztürk, İ. G., (2010). İstanbul Üniversitesi Adana, Osmaniye, Hatay ve Mersin İlleri 2008 Y1lı Eskiçağ Yerleşim Arkeolojisi ve Tarihi-Coğrafya Araştırmaları, XXVII. Araştırma Sonuçları Toplantısı-I, İsmail Aygül Ofset Matbaacılık, s. 247250, 453-458, Ankara.

Strabon., (1993). Antik Anadolu Coğrafyası-Geographika Kitap XII-XIII-XIV, s.14-16. İstanbul.

Şahin, Durgun, Y., (2019). Ovalık Kilikya Bölgesi Roma Antik Kentlerinin Mekân Dizim Yöntemi ile Analizi. Doktora Tezi. Çukurova Üniversitesi Fen Bilimleri Enstitüsü, Peyzaj Mimarlığı Anabilim Dalı. Adana.

Şahin, R., (2014). Karataş Burnu Yüzey Araştırmasında Bulunan Hellenistik ve Roma Dönemi Keramikleri. TÜBA-AR-17.

Tahberer, B., (2005). Antik Kilikya Sikkelerinde Asklepios Kültü. Ç.Ü. Sağlı Bilimleri Enstitüsü, Deontoloji ve Tıp Tarihi Anabilim Dalı, Yüksek Lisans Tezi, Adana.

Tanaç, M. (2000). Batı Anadolu Antik Yerleşimlerinde Kentsel Mekân Kurgusu Araştırması, Yüksek Lisans Tezi, Dokuz Eylül Üniversitesi, İzmir.

Ünal, A. Girginer, K, S., (2007). Kilikya-Çukurova, İlk Çağlardan Osmanlılar Dönemine Kadar Kilikya'da Tarihi Coğrafya, Tarih ve Arkeoloji, s.226. İstanbul.

Ünal, A., (2006). Hitit İmparatorluğunun Yıkılışından Bizans Döneminin Sonuna Kadar Adana ve Çukurova Tarihi. Çukurova Üniversitesi Sosyal Bilimler Enstitüsü Dergisi Cilt 15 Sayı 3, s. 67-102, Adana.

Ünlü, T, S., (2017), Kent Kimliğinin Oluşumunda Kentsel Bellek ve Kentsel Mekân İlişkisi: Mersin Örneği. Planlama, 27(1):75-93.

Verner, R., (1951). Eine Griechische Inschrift Aus Karataş, Jahrbuch für Kleinasiatische Forschung I, p. 256-259, 325-327, Heidenbur. Williams, S. V. (1954). Cilicia Survey, Anatolian StudiesVol 4, p.121-174, Ankara.

Wycherley, R, E., (2011). Antik Çağda Kentler Nasıl Kuruldu? Arkeoloji ve Sanat Yayınları. 4. Baskı.İstanbul. 